\title{
Changes in Fish Communities of Lake Ontario Coastal Wetlands before and after Remedial Action Plans
}

\author{
Titus Seilheimer, Anhua Wei, and Patricia Chow-Fraser \\ Department of Biology, McMaster University, Hamilton, ON, Canada L8S 4K1 \\ Correspondence should be addressed to Titus Seilheimer, titus.seilheimer@gmail.com
}

Received 23 January 2011; Accepted 7 March 2011

Academic Editors: D. Gerten and C. Rixen

Copyright (๑) 2011 Titus Seilheimer et al. This is an open access article distributed under the Creative Commons Attribution License, which permits unrestricted use, distribution, and reproduction in any medium, provided the original work is properly cited.

\begin{abstract}
We conducted a change-detection analysis to determine if improvements in the habitat quality of coastal wetlands could be attributed to Remedial Action Plans (RAPs) of Lake Ontario. We used a 5-km buffer relative to each recent site to "resample" an existing database of spawning/nursery habitat from the early 1980s to derive a "historic" species list associated with thirteen representative wetlands sampled in 2001-2002. For each wetland, we calculated Wetland Fish Index (WFI) scores, which are relative measures of wetland quality having scores ranging from 1 to 5 , indicating worst to best conditions, respectively. The mean WFI score of 3.16 for the recent era was significantly higher than that for the historic era of 2.79 (Wilcoxon sign-rank test; $P=.04$ ), and this is consistent with the conclusion that lakewide RAPs have been effective in recovering some of the ecological functions of degraded coastal wetlands of Lake Ontario.
\end{abstract}

\section{Introduction}

The Laurentian Great Lakes have been subjected to anthropogenic stress since European settlement in the region in the late 1700s. Degraded water quality led to declines in fish stocks and quality of habitat. In response to degraded water quality, the Great Lakes Water Quality Agreement (GLWQA) of 1972 was enacted, which set limits on the amount of phosphorus entering the system. Additional steps to improve the lakes occurred in 1978 through identification of Areas of Concern (AOC), sites within the Great Lakes that had impairment of beneficial uses (e.g., fish habitat and eutrophication). Of the 14 defined beneficial uses, 5 are directly referring to fish (see Table 1 ). Remedial Action Plans (RAPs) were developed for each AOC, in order to identify the problems, set remediation goals, and monitor improvement until beneficial uses are restored. There are 8 AOC sites throughout the Lake Ontario shoreline, with differing problems and losses of beneficial uses, which affect fish habitat on multiple levels ([1]; Table 1). Billions of dollars have already been spent on restoring beneficial uses, with anticipated costs for improvement to wastewater infrastructure and sediment remediation alone estimated at \$7.4 billon (USD) in United States AOCs and \$1.9 billion (CAD) for Canadian AOCs [1]. Habitat restoration costs for 187 restoration projects completed in Canadian AOCs total $\$ 80.3$ million (CAD; [1]).

Jude and Pappas [2] demonstrated that wetlands are important fish habitat by showing that 47 of 113 Great Lake fish species were closely associated with wetlands, while an additional 35 used wetlands during some life stage. Wei et al. [3] demonstrated empirically the dependence of Great Lakes fishes on availability of coastal marshes for spawning and nursery habitat throughout the entire Great Lakes shoreline. Hence, coastal wetlands of Lake Ontario are assumed to provide critical fish habitat for the Lake Ontario fish community. Unfortunately, many coastal marshes have been drastically altered over the last 300 years. Nearly $60 \%$ of the original wetlands have been lost on the Canadian shoreline of Lake Ontario, with even higher loss along the shoreline between Toronto and the Niagara River [4]. The remaining wetlands face potential decreases in quality due to urbanization and other anthropogenic impacts [5]. 
TABle 1: Impairment of beneficial uses and stage of Remedial Action Plans for Lake Ontario Areas of Concern. Beneficial use impairments are (1) restrictions on fish and wildlife consumption, (2) tainting of fish and wildlife flavor, (3) degradation of fish and wildlife populations, (4) fish tumors or other deformities, (5) bird or animal deformities or reproduction problems, (6) degradation of benthos, (7) restrictions on dredging activities, (8) eutrophication or undesirable algae, (9) restrictions on drinking water consumption, (10) beach closings, (11) degradation of aesthetics, (12) added costs to agriculture or industry, (13) degradation of phytoplankton and zooplankton populations, (14) loss of fish and wildlife habitat.

\begin{tabular}{lccccccccccccccccc}
\hline Area of concern & Stage & 1 & 2 & 3 & 4 & 5 & 6 & 7 & 8 & 9 & 10 & 11 & 12 & 13 & 14 & Total \\
\hline Hamilton Harbour, ON & 2 & $\mathrm{X}$ & - & $\mathrm{X}$ & $\mathrm{X}$ & $\mathrm{X}$ & $\mathrm{X}$ & $\mathrm{X}$ & $\mathrm{X}$ & - & $\mathrm{X}$ & $\mathrm{X}$ & - & $\mathrm{X}$ & $\mathrm{X}$ & 11 \\
Toronto and Region, ON & 2 & $\mathrm{X}$ & - & $\mathrm{X}$ & - & - & $\mathrm{X}$ & $\mathrm{X}$ & $\mathrm{X}$ & - & $\mathrm{X}$ & $\mathrm{X}$ & - & & $\mathrm{X}$ & 8 \\
Port Hope, ON & 1 & - & - & - & - & - & - & $\mathrm{X}$ & - & - & - & - & - & - & - & 1 \\
Bay of Quinte, ON & 2 & $\mathrm{X}$ & - & $\mathrm{X}$ & - & - & $\mathrm{X}$ & $\mathrm{X}$ & $\mathrm{X}$ & $\mathrm{X}$ & $\mathrm{X}$ & $\mathrm{X}$ & - & $\mathrm{X}$ & $\mathrm{X}$ & 10 \\
Oswego River, NY & 2 & $\mathrm{X}$ & - & $\mathrm{X}$ & - & - & - & - & $\mathrm{X}$ & - & - & - & - & - & $\mathrm{X}$ & 4 \\
Rochester Embayment, NY & 2 & $\mathrm{X}$ & - & $\mathrm{X}$ & - & $\mathrm{X}$ & $\mathrm{X}$ & $\mathrm{X}$ & $\mathrm{X}$ & $\mathrm{X}$ & $\mathrm{X}$ & $\mathrm{X}$ & $\mathrm{X}$ & $\mathrm{X}$ & $\mathrm{X}$ & 12 \\
Eighteen Mile Creek, NY & 2 & $\mathrm{X}$ & - & - & - & - & $\mathrm{X}$ & $\mathrm{X}$ & - & - & - & - & - & - & - & 3 \\
Niagara River, ON, NY & 2 & $\mathrm{X}$ & - & - & $\mathrm{X}$ & - & $\mathrm{X}$ & $\mathrm{X}$ & - & - & - & - & - & - & $\mathrm{X}$ & 5 \\
\hline
\end{tabular}

Change in the response of aquatic biota to environmental perturbation has been used as a measure of ecosystem health in many aquatic habitats (e.g., streams, lakes, and Great Lakes) with multiple trophic levels: plants [6], zooplankton [7], and macroinvertebrates [8]. The Index of Biotic Integrity (IBI; [9]) is a widely used measurement of habitat quality and ecosystem health based on fish-community data in relation to known reference conditions, and has been used to assess environmental quality $[10,11]$ and to monitor restoration efforts. Two IBIs have been developed for use in the Lake Ontario basin: in littoral habitat of AOCs [12] and in tributaries of the Greater Toronto area [13]. Likewise, the Wetland Fish Index (WFI; [14]) was developed to rank Great Lakes wetlands with fish assemblage data. Unlike the IBI, the WFI can be calculated with presence-absence fish data only, which is often the only data available for historical species lists and datasets.

Although site-by-site comparison of fish is useful, fish are migratory and need to be studied on a lake-wide scale. Some aspects of the Lake Ontario fish community have been monitored over time on a large spatial scale in open water (salmonids and commercial fish; [15]). By comparison, there has been no comprehensive study of changes in the quality of critical habitat such as wetlands since implementation of the RAPs in the early 1980s. A common lament from government officials who fund these remedial actions is that benefits to fish and wildlife populations are not well quantified and are infrequently reported. To fully determine the far-reaching impacts of RAPs, we need to track both temporal and spatial changes in the fish communities of Lake Ontario, not only in open water, where most of the current effort is focused, but also in wetlands that occur at river mouths and at lake margins. We therefore need to conduct a basin-wide assessment of the change in status of Lake Ontario coastal wetlands in response to remedial actions.

It was difficult to find a primary source that could provide the sort of parallel information to do a lakewide assessment before and after the implementation of RAPs. However, we were able to use information from two recently published studies to derive the necessary information to assess temporal and spatial changes: for historic information, we used the GIS database of Wei et al. [3], which contains locations where Great Lakes fish are known to have spawning and nursery habitat along the entire Lake Ontario shoreline (determined from field surveys and current as of the early 1980s), and for the present day dataset, we used Seilheimer and Chow-Fraser's [14] data, which consisted of standardized fish surveys conducted in 24 coastal wetlands of Lake Ontario during 2001 and 2002.

We have three main objectives in this study. First we will determine if fish biodiversity in the coastal wetlands surveyed in the recent era has changed significantly compared with data from the early 1980s, prior to implementation of RAPs. Secondly, we will calculate WFI scores for these wetlands to quantify the change in habitat quality between time periods. Thirdly, we will determine if proximity of sites to AOCs can be statistically related to improved habitat quality, as determined by an increase in WFI scores in the recent era. These results will help us evaluate the overall effectiveness of RAPs on wetlands in the Lake Ontario ecosystem, and will help demonstrate the usefulness of WFI as an indicator of wetland quality, especially when only species lists are available to be used as a benchmark of change.

\section{Methods}

2.1. Study Site. Lake Ontario is the smallest of the Laurentian Great Lakes and the last in the chain, with water entering from the other four Great Lakes via the Niagara River and exiting to the Atlantic Ocean via the St. Lawrence River. $49 \%$ of the drainage basin in Lake Ontario is forested, 39\% is agricultural, and the remaining $7 \%$ is urban area [16]. Almost three quarters of the approximately 6 million people living in the basin are in the province of Ontario, Canada [15], with the majority living in the highly urbanized western end of the lake between Hamilton and Toronto, Ontario. There are 8 AOCs in Lake Ontario (Figure 1). Of the 14 beneficial uses outlined in the GLWQA Annex 2 (Table 1), Lake Ontario AOCs range from having only 1 impaired use 


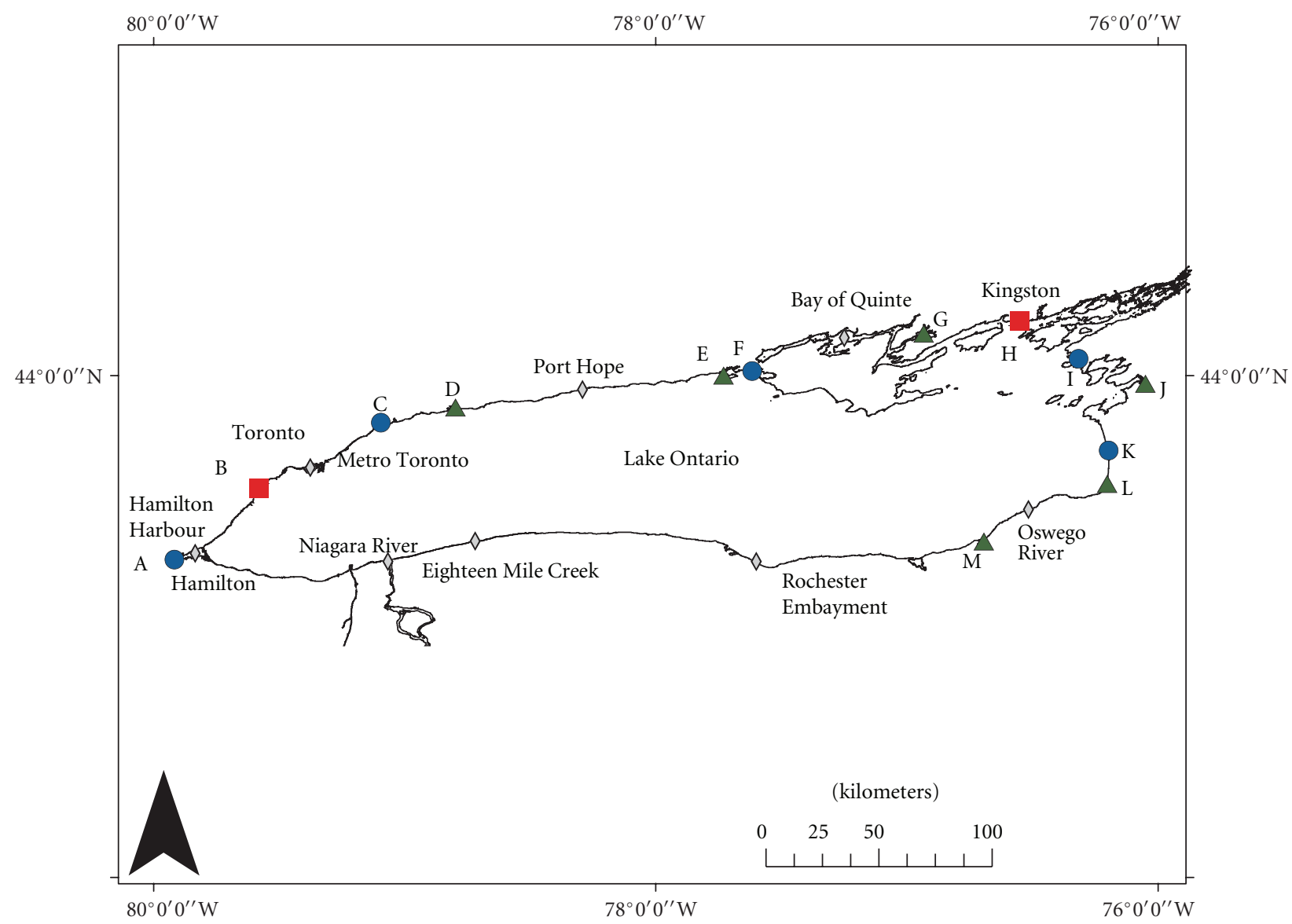

Figure 1: Study wetlands (see Table 2 for site codes) and Areas of Concern (marked with diamonds) in Lake Ontario. Study site shapes indicate degree of change between historical and recent datasets (red square indicates worsened conditions, blue circle indicates minimal change, and green triangle indicates improved conditions). Location of Hamilton, Toronto, and Kingston is in italics.

(Port Hope, ON) to 12 (Rochester Embayment, NY; Table 1). In addition to Rochester, 3 Ontario AOCs have multiple impaired uses: Hamilton Harbour (11), Toronto and Region (8), and the Bay of Quinte (10; Table 1). AOCs are equally distributed around the lake and between the two countries Ontario has 4 AOC, New York has 3, and one is shared by both countries (Niagara River). All of the Lake Ontario RAPs are in the second stage (restoration of impairments) except Port Hope, which is only at stage 1 but is not located near our sites (Figure 1).

2.2. Data Used in this Study. Fish species lists were obtained from the study published by Seilheimer and Chow-Fraser [14], and corresponding water-quality information was obtained from Chow-Fraser [5] (see location of wetlands in Figure 1). Although Seilheimer and Chow-Fraser [14] surveyed 24 wetlands during the summer of 2002 throughout the Lake Ontario shoreline, there was only comparable historic information for 13 sites (see Table 2). Fish were surveyed in the recent study with 3 sets of paired fyke nets that were set overnight in each wetland, and water samples were collected simultaneously in an open water area close to the nets. Wetland habitats sampled were primarily marsh habitat in river mouths or protected bay that were connected to Lake Ontario for part or all of the year. Paired fyke nets were connected by a $10 \mathrm{~m}$ lead and set parallel to vegetation in waters less than 2 meters. Fish species were identified in the field and returned to the capture site. We followed the method developed by Chow-Fraser [5] and Seilheimer and Chow-Fraser [14] to calculate Water Quality Index (WQI) and Wetland Fish Index (WFI) scores for each wetland. The complete field protocols used to collect fish and water-quality information can be found in the cited studies. The WFI is calculated by tallying a total score of fish species-specific tolerance to degradation and range of conditions found in each site with the following formula:

$$
\mathrm{WFI}=\frac{\sum_{i=1}^{n} Y_{i} T_{i} U_{i}}{\sum_{i=1}^{n} Y_{i} T_{i}}
$$

where $Y$ is 1 for each species present, $U$ values range from 1 to 5 where species with $U=1$ occurs in most degraded wetlands and $U=5$ occurs in the least degraded wetlands, and $T$ values range from 1 to 3 where $T=1$ occur in a wide range of habitats and $U=3$ occur in a narrow range of habitats. The range of scores for the WFI is 1 to 5 , with 1 indicating degraded conditions (e.g., high nutrients and turbidity) and 5 indicating low degradation (e.g., low nutrients and turbidity). Since the Wetland Fish 
TABLE 2: Comparison of habitat quality of 13 wetlands in this study, along with corresponding WQI (Water Quality Index) scores for the recent era and Wetland Fish Index (WFI) scores for both historic and recent periods. Historic sampling effort represents the total number of locations of fishes within $5 \mathrm{~km}$ of each site. Difference was calculated by subtracting historic WFI score from the recent value. Numbers below the means are the SE. $P$ value is presented for 2-tailed Wilcoxon sign-rank test for WFI score in two time periods. WQI scores should be interpreted as follows: -3 to -2 (highly degraded); -2 to -1 (very degraded); -1 to 0 (moderately degraded); 0 to 1 (good); $1-2$ (very good).

\begin{tabular}{|c|c|c|c|c|c|c|c|c|}
\hline \multirow[b]{2}{*}{ Wetland name } & \multirow[b]{2}{*}{$\begin{array}{l}\text { Site } \\
\text { code }\end{array}$} & \multirow[b]{2}{*}{ Lat } & \multirow[b]{2}{*}{ Long } & \multirow[b]{2}{*}{$\begin{array}{c}\text { Historic } \\
\text { sampling effort }\end{array}$} & \multirow[b]{2}{*}{$\begin{array}{l}\text { WQI } \\
\text { score }\end{array}$} & \multicolumn{3}{|c|}{ WFI Scores } \\
\hline & & & & & & Historic & Recent & Difference \\
\hline Cootes Paradise/Grindstone Creek & A & 43.267 & -79.917 & 3 & -1.62 & 2.56 & 2.50 & -0.06 \\
\hline Credit River & B & 43.550 & -79.580 & 2 & -1.48 & 3.09 & 2.57 & -0.52 \\
\hline Frenchman's Bay & $\mathrm{C}$ & 43.812 & -79.095 & 3 & -0.53 & 2.73 & 2.60 & -0.13 \\
\hline Darlington Provincial Park & $\mathrm{D}$ & 43.873 & -78.797 & 2 & -1.16 & 2.20 & 2.62 & +0.42 \\
\hline Presqu'ile Provincial Park & $\mathrm{E}$ & 44.000 & -77.731 & 1 & 0.47 & 2.00 & 3.43 & +1.43 \\
\hline Wellers Bay & $\mathrm{F}$ & 44.017 & -77.617 & 1 & 1.00 & 3.50 & 3.42 & -0.08 \\
\hline Hay Bay Marsh & G & 44.167 & -76.933 & 1 & 0.45 & 1.80 & 3.53 & +1.73 \\
\hline Little Cataraqui Creek & $\mathrm{H}$ & 44.217 & -76.550 & 1 & -1.28 & 3.67 & 3.44 & -0.23 \\
\hline Mud Bay & I & 44.067 & -76.317 & 3 & -0.72 & 3.04 & 3.20 & +0.16 \\
\hline Perch River/Muskellunge River & $\mathrm{J}$ & 43.967 & -76.050 & 2 & -0.15 & 2.79 & 3.44 & +0.65 \\
\hline Sandy Creek & K & 43.701 & -76.196 & 2 & 1.06 & 3.09 & 3.38 & +0.29 \\
\hline Salmon River & $\mathrm{L}$ & 43.568 & -76.202 & 2 & 1.28 & 3.11 & 3.65 & +0.54 \\
\hline Little Sodus & M & 43.339 & -76.694 & 3 & 0.33 & 2.73 & 3.30 & +0.57 \\
\hline \multirow[t]{3}{*}{ Mean score } & & & & & -0.18 & 2.79 & 3.16 & +0.36 \\
\hline & & & & & $(0.28)$ & $(0.15)$ & $(0.12)$ & $(0.18)$ \\
\hline & & & & & & $P$ value & .04 & \\
\hline
\end{tabular}

Index only requires presence/absence data, WFI scores could easily be calculated for both time periods for comparison purposes. The WQI score had been developed from waterquality data collected from 110 wetlands located throughout the five Great Lakes and is significantly correlated with the proportion of altered land in wetland watersheds [5]. WQI scores are calculated using 12 environmental variables, including physical, chemical, nutrient, and biological (e.g., chlorophyll a) variables, with scores that range from -3 , which is indicative of the most impacted conditions, to +3 , which is indicative of the most undisturbed sites.

The source of historic fish information (circa 1980s) was published by Goodyear et al. [17] in the "Atlas of the Spawning and Nursery Areas of Great Lakes Fishes." The Atlas is a 14-volume collection of historical records and locations of fish spawning locations throughout the Great Lakes. We "resampled" a GIS database created by Wei et al. [3] that included all the georeferenced records of fish occurrence from the database of Goodyear et al. [17]. This was accomplished by setting a buffer (5-km radius) around the centroid of each of the thirteen wetlands and using ArcView (ESRI, version 8.2) to determine the species of fish that were entrained by the buffer. Estimated sampling effort in the historical database (Table 2) was derived by counting the number of separate spatial coordinates near each site. Effort ranged from 1 to 3 separate fish locations for each site, which is comparable to the 3 fyke nets set at each wetland in the recent survey. The resulting species list constituted the historic dataset, which we used to compare with the species list from the recent survey.

We acknowledge that the comparison of data from the recent survey with data derived from the Goodyear et al. [17] dataset is not ideal because of differences in survey method and effort used between studies, but we feel that the comparison is valid because all sites in each time period had received the same treatment. There may be bias in the historic dataset, but we have been conservative in our analyses with the comparison of presence-absence data only. In the absence of more suitable data, we must use what is available, while acknowledging potential problems.

2.3. Statistical Analysis. Comparison of species richness, family richness, and number of species per family, was tested with paired $t$-tests. Differences in WFI scores between historic and recent surveys were tested with the nonparametric Wilcoxon sign-rank test (alpha $=0.05 ;[18])$. Differences between WFI scores for the two time periods for three locations in Lake Ontario (East New York, East Ontario, and West Ontario) and distance to AOC sites (0-20 km, 20$40 \mathrm{~km}$, and $40+\mathrm{km}$ ) were tested with ANOVA and TukeyKramer post hoc test (alpha $=0.05)$. All statistical tests were performed in SAS JMP (version 8.0, SAS Institute Inc., Cary NC). The Benjamini-Hochberg method was used to 
TABle 3: Mean total number of families, species, and species in Centrarchidae, Cyprinidae, Ictaluridae, Percidae, and Moronidae families occurring in 13 sites in historical and recent time periods. Mean richness found in each wetland was compared with a 2tailed $t$-test to determine significant differences between eras (bold indicates significant differences).

\begin{tabular}{lccc}
\hline Mean richness in wetland & Historic & Recent & $P$-value \\
\hline Family & 5.5 & 7.0 & .12 \\
Species & $\mathbf{7 . 6}$ & $\mathbf{1 2 . 5}$ & .01 \\
Centrarchidae species & $\mathbf{1 . 9}$ & $\mathbf{3 . 6}$ & .02 \\
Cyprinidae species & $\mathbf{1 . 3}$ & $\mathbf{2 . 8}$ & .03 \\
Ictaluridae species & $\mathbf{0 . 6}$ & $\mathbf{1 . 6}$ & .01 \\
Percidae species & 0.8 & 1.2 & .09 \\
Moronidae species & $\mathbf{0 . 6}$ & $\mathbf{0 . 2}$ & .02 \\
\hline
\end{tabular}

adjust the $P$ values and account for the false discovery rate from multiple tests [19]. The $P$-values presented throughout the study have been adjusted with the Benjamini-Hochberg method and are significant at an alpha of 0.05 .

\section{Results}

According to WQI values taken from Chow-Fraser [5], 4 of the wetlands in this study currently are "very degraded" (Cootes Paradise Marsh/Grindstone Creek and Credit River, Darlington Provincial Park, Little Cataraqui Creek), 3 are "moderately degraded" (Frenchman's Bay, Mud Bay/Perch River, and Muskellunge River), and 4 are in "good" quality (Presqu' ile Provincial Park, Weller's Bay, Hay Bay Marsh, and Little Sodus), while the remaining two have "very good" quality (Salmon River and Sandy Creek) (Table 2). For the most part, the poor-quality sites are all associated with cities at both the western and eastern ends of Lake Ontario (see Figure 1). The better-quality sites are found in the eastern portion of the lake, along the US shoreline, where landuse is primarily forested and undisturbed. By comparison, conditions of wetlands located on the Canadian shoreline in the eastern portion of Lake Ontario were considered better than those in urban landscapes, but not as good quality as those in primarily undisturbed watersheds, and this may reflect the low-intensity farming that occurs along the shores of many of the wetlands in the Bay of Quinte area.

We first reviewed the datasets to determine if there had been differences in species richness and taxonomic composition (see Tables 6 and 7 for fish occurrence by location). There were more families associated with the recent era (7.0) compared with the historic (5.5) era, although this was not statistically significant $(P=.11$; Table 3). When all of the wetlands were considered together, we found a total of 25 species in the historic dataset, which was considerably lower than the 39 in the recent dataset $(P=.01$; Table 3$)$. Three of the eight Centrarchidae species (i.e., pumpkinseed Lepomis gibbosus, bluegills Lepomis macrochirus, and rockbass Ambloplites rupestris) were found more often in recent surveys (Table 4). Although only the Freshwater drum Aplodinotus grunniens was found exclusively in the historic dataset, 16 species were found only in recent times (Table 4). Twelve of these unique species could be considered rare (i.e., occurred in fewer than 3 wetlands), and their absence in the historic list could be attributed to insufficient sampling effort; however, the other four species occurred in close to $40 \%$ of the wetlands (5 of 13) surveyed, and two in particular, the bowfin Amia calva and bluegill, were conspicuously present in $>75 \%$ of the wetlands (10 of 13). Therefore, appearance of these latter four in the recent dataset when they had not been noticed in any of the 13 wetlands two decades earlier deserves some further attention. By comparison, only four species occurred more frequently (i.e., at least 5 more sites in historic than in recent) in the historic compared with recent surveys, and these included smallmouth bass Micropterus dolomieu, white sucker Catostomus commersonii, white perch, and the northern pike Esox lucius.

We further grouped the fish species into families to examine their distributions across wetlands in both time periods. There was sufficient information for five families to conduct statistical comparisons (Table 3). There were significantly more species within the Centrarchidae (bass and sunfish; 3.63 versus 1.77; $P=.02$ ), Cyprinidae (minnows and shiners; 2.92 versus $1.00 ; P=.03$ ), and Ictaluridae (bullhead; 1.6 versus $0.6 ; P=.01$ ) families in recent years. By comparison, there were not significant differences for Percidae (perch and darters; $P=.09$ ), while the number of Moronidae (white perch Morone americana and white bass $M$. chrysops) species has actually declined in recent years $(0.62$ versus $0.15 ; P=.02)$.

WFI scores corresponding to the two time periods were generated for each wetland (Figure 1, Table 2). For two sites, Cootes Paradise/Grindstone Creek and Wellers Bay, WFI scores differed minimally $(<0.1$ unit) between time periods and we interpret this to mean that there has been no change in wetland quality over the two decades. For three sites, Credit River, Frenchman's Bay, and Little Cataraqui Creek, there was a decrease in WFI scores through the two decades. By contrast, scores for the remaining eight sites were generally much higher for the recent era (Table 2), and this was especially evident for Presqu'ile Provincial Park and Hay Bay Marsh, where differences between time periods were +1.43 and +1.73 , resp. When data were pooled by time periods and compared, we found a significant increase in WFI scores from the 1980s to 2000 s (2.79 versus 3.16 , respectively; two-tailed Wilcoxon sign-rank test, $P=.04$; Table 2). Our data therefore indicate that the habitat quality of wetlands has improved significantly following implementation of RAPs around Lake Ontario.

There was a significant linear relationship between the recent WFI scores $\left(r^{2}=0.57, P<.01\right)$ and the recent WQI scores (see data in Table 2); however, there was no relationship between the historical WFI scores and the recent WQI scores. Mean WQI scores were significantly lower in the western sites $(-1.20)$ compared with the eastern Ontario and New York sites, 0.16 and 0.36 , respectively ( $t$-test $P=.04$ ). WFI scores were higher at wetlands farther from RAP sites 
TABLE 4: Comparison of species occurrences between the historic and recent surveys in Lake Ontario.

\begin{tabular}{|c|c|c|c|c|}
\hline \multirow[b]{2}{*}{ Family } & \multirow[b]{2}{*}{ Common name } & \multirow[b]{2}{*}{ Scientific name } & \multicolumn{2}{|c|}{ Number of sites present } \\
\hline & & & Historic & Recent \\
\hline Amiidae & Bowfin & Amia calva & 0 & 10 \\
\hline Anguillidae & American eel & Anguilla rostrata & 0 & 1 \\
\hline Atherinopsidae & Brook silverside & Labidesthes sicculus & 0 & 1 \\
\hline Catostomidae & White sucker & Catostomus commersonii & 7 & 1 \\
\hline \multirow[t]{8}{*}{ Centrarchidae } & Rockbass & Ambloplites rupestris & 3 & 10 \\
\hline & Green sunfish & Lepomis cyanellus & 0 & 1 \\
\hline & Pumpkinseed & Lepomis gibbosus & 2 & 13 \\
\hline & Bluegill & Lepomis macrochirus & 0 & 8 \\
\hline & Smallmouth bass & Micropterus dolomieu & 9 & 1 \\
\hline & Largemouth bass & Micropterus salmoides & 7 & 9 \\
\hline & White crappie & Pomoxis annularis & 0 & 3 \\
\hline & Black crappie & Pomoxis nigromaculatus & 4 & 2 \\
\hline \multirow[t]{2}{*}{ Clupeidae } & Alewife & Alosa pseudoharengus & 6 & 4 \\
\hline & Gizzard shad & Dorosoma cepedianum & 2 & 3 \\
\hline \multirow[t]{11}{*}{ Cyprinidae } & Goldfish & Carassius auratus & 1 & 1 \\
\hline & Spotfin shiner & Cyprinella spiloptera & 0 & 2 \\
\hline & Common carp & Cyprinus carpio & 7 & 6 \\
\hline & Brassy minnow & Hybognathus hankinsoni & 0 & 1 \\
\hline & Golden shiner & Notemigonus crysoleucas & 1 & 5 \\
\hline & Emerald shiner & Notropis atherinoides & 3 & 2 \\
\hline & Blacknose shiner & Notropis heterolepis & 0 & 2 \\
\hline & Spottail shiner & Notropis hudsonius & 2 & 4 \\
\hline & Sand shiner & Notropis stramineus & 0 & 1 \\
\hline & Bluntnose minnow & Pimephales notatus & 2 & 8 \\
\hline & Fathead minnow & Pimephales promelas & 1 & 5 \\
\hline \multirow[t]{2}{*}{ Esocidae } & Northern pike & Esox lucius & 10 & 5 \\
\hline & Redfin pickerel & Esox americanus & 0 & 1 \\
\hline Fundulidae & Banded killifish & Fundulus diaphanus & 1 & 7 \\
\hline Gasterosteidae & Threespine stickleback & Gasterosteus aculeatus & 4 & 2 \\
\hline \multirow[t]{4}{*}{ Ictaluridae } & Black bullhead & Ameiurus melas & 0 & 1 \\
\hline & Brown bullhead & Ameiurus nebulosus & 7 & 13 \\
\hline & Channel catfish & Ictalurus punctatus & 1 & 1 \\
\hline & Tadpole madtom & Noturus gyrinus & 0 & 6 \\
\hline Lepisosteidae & Longnose gar & Lepisosteus osseus & 0 & 1 \\
\hline \multirow[t]{2}{*}{ Moronidae } & White perch & Morone americana & 7 & 1 \\
\hline & White bass & Morone chrysops & 1 & 1 \\
\hline \multirow[t]{2}{*}{ Percidae } & Johnny darter & Etheostoma nigrum & 2 & 3 \\
\hline & Yellow perch & Perca flavescens & 8 & 12 \\
\hline Sciaenidae & Freshwater drum & Aplodinotus grunniens & 1 & 0 \\
\hline Umbridae & Central mudminnow & Umbra limi & 0 & 5 \\
\hline
\end{tabular}


TABLE 5: Comparison of mean and standard errors (SEs) of WFI scores for three categories of wetlands, sorted by distance (km) to RAP sites around Lake Ontario. Significant differences among categories are indicated by letters (a, b, c; ANOVA) and differences between time periods are indicated by numbers $(1,2$; paired $t$-test).

\begin{tabular}{|c|c|c|c|c|c|}
\hline \multirow{2}{*}{ Distance $(\mathrm{km})$} & \multirow{2}{*}{$n$} & \multicolumn{2}{|c|}{ Historic } & \multicolumn{2}{|c|}{ Recent } \\
\hline & & Mean & SE & Mean & SE \\
\hline $0-20$ & 4 & $2.55^{\mathrm{al}}$ & 0.27 & $2.77^{\mathrm{al}}$ & 0.24 \\
\hline $20-40$ & 4 & $2.78^{\mathrm{al}}$ & 0.24 & $3.24^{\mathrm{a} 2}$ & 0.22 \\
\hline $40+$ & 5 & $3.00^{a 1}$ & 0.29 & $3.39^{\mathrm{al}}$ & 0.05 \\
\hline \multirow{2}{*}{ Location } & \multirow{2}{*}{$n$} & \multicolumn{2}{|c|}{ Historic } & \multicolumn{2}{|c|}{ Recent } \\
\hline & & Mean & SE & Mean & SE \\
\hline East New York & 5 & $2.95^{\mathrm{al}}$ & 0.07 & $3.40^{\mathrm{a} 2}$ & 0.08 \\
\hline East Ontario & 4 & $2.74^{\mathrm{al}}$ & 0.49 & $3.45^{\mathrm{a} 1}$ & 0.02 \\
\hline West Ontario & 4 & $2.65^{\mathrm{al}}$ & 0.19 & $2.54^{\mathrm{b} 1}$ & 0.03 \\
\hline
\end{tabular}

in Lake Ontario, although scores were only significantly different for the $20-40 \mathrm{~km}$ category (Table 5). For wetlands located in the US shoreline (southeastern portion of the lake; see Figure 1), WFI scores were significantly higher in the recent survey (3.40) compared with the historic survey (2.95), and this trend was reproduced for the eastern sites on the Canadian shoreline, although the means were not significantly different between time periods. By contrast, sites located in western Ontario showed a deterioration in quality through time with corresponding decrease in WFI score of 2.65 to 2.54 (paired $t$-test; $P<.05$ ).

\section{Discussion}

The first objective of this study was to determine how species richness and diversity of species within families have changed across wetlands following implementation of lake-wide Remedial Action Plans in the late 1980s and the early 1990s. Species richness can be used as a measure of diversity in a habitat [20] and can be monitored over time to track changes. We have documented significant changes in the fish communities before and after RAPs in two ways. First, mean species richness in the thirteen wetlands has increased significantly over the two decades (Table 3). There has been an overall increase from 24 species in the historic survey to 40 in the recent survey; even if we removed the rare species (occurring in 2 or fewer wetlands), the comparison would be 11 versus 19 species for historic and recent periods, respectively (Table 4 ). Secondly, the mean number of Centrarchidae, Cyprinidae, and Ictaluridae species in the 13 wetlands has significantly increased through time, while the mean number of Moronidae species has significantly declined (Table 3 ). These changes in fish communities are reflected in significant differences in mean Wetland Fish Index scores, which indicate that habitat quality in the thirteen coastal wetland complexes has generally improved following implementation of RAPs (Table 2).
Watershed development and urbanization are known to have negative effects on fish habitat at a local scale [21, 22]. The four sites that yielded decreased WFI scores following RAPs were all surrounded by urbanized land use: three wetlands located in the highly urbanized western end of Lake Ontario between the Ontario cities of Hamilton and Pickering and one located at the eastern end within the city of Kingston, ON (see Figure 1). Wei and Chow-Fraser [23] have documented the separate and synergistic effects of urbanization and fluctuating water level on the emergent marsh of Cootes Paradise Marsh, which is located in the city of Hamilton, ON. Findings from this study confirm the hypothesis that the negative effect of increased population growth in wetland watersheds may trump any benefits of inmarsh habitat restorations such as carp exclusion or creation of habitat structure and complexity. Since more than 6 million Canadians currently live in the western end of Lake Ontario [24], and there are no plans for zero-growth, the long-term prognosis for marshes in these heavily urbanized watersheds is not favorable and more effort must be focused on a comprehensive program to control nonpoint source pollution.

Since the WFI is an index of wetland condition that reflects the degree of human disturbance on water quality [14], it is ideal for detecting long-term changes in waterquality conditions of wetlands. The significant relationship between recent WFI and WQI scores noted in this study confirms that the Wetland Fish Index can be used as a surrogate of water-quality parameters at the scale of Lake Ontario. Seilheimer and Chow-Fraser [14] have also shown it to be sensitive to track both temporal and spatial changes in wetland quality within a relatively small coastal marsh (Frenchman's Bay) that has multiple points of entry for pollutants. An advantage of the WFI is that it can be calculated with presence-absence data alone, unlike Minns et al.'s [12] Fish IBI for AOCs, which has 7 of its 12 metrics requiring biomass and abundance data. As we have discovered in this study, species lists are often the only historical information available on a regional basis, and consequently, indices based primarily on abundance information cannot be used. 
Table 6: Historic fish occurrence. See Table 2 for site codes.

\begin{tabular}{|c|c|c|c|c|c|c|c|c|c|c|c|c|c|c|}
\hline \multirow[b]{2}{*}{ Family } & \multirow[b]{2}{*}{ Scientific name } & \multicolumn{13}{|c|}{ Historic fish collection } \\
\hline & & A & B & $\mathrm{C}$ & $\mathrm{D}$ & $\mathrm{E}$ & $\mathrm{F}$ & G & $\mathrm{H}$ & I & $\mathrm{J}$ & K & $\mathrm{L}$ & M \\
\hline Amiidae & Amia calva & 0 & 0 & 0 & 0 & 0 & 0 & 0 & 0 & 0 & 0 & 0 & 0 & 0 \\
\hline Anguillidae & Anguilla rostrata & 0 & 0 & 0 & 0 & 0 & 0 & 0 & 0 & 0 & 0 & 0 & 0 & 0 \\
\hline Atherinopsidae & Labidesthes sicculus & 0 & 0 & 0 & 0 & 0 & 0 & 0 & 0 & 0 & 0 & 0 & 0 & 0 \\
\hline Catostomidae & Catostomus commersonii & 1 & 1 & 1 & 1 & 0 & 0 & 0 & 0 & 1 & 1 & 0 & 1 & 0 \\
\hline \multirow[t]{8}{*}{ Centrarchidae } & Ambloplites rupestris & 0 & 0 & 1 & 0 & 0 & 0 & 0 & 0 & 1 & 0 & 0 & 0 & 1 \\
\hline & Lepomis cyanellus & 0 & 0 & 0 & 0 & 0 & 0 & 0 & 0 & 0 & 0 & 0 & 0 & 0 \\
\hline & Lepomis gibbosus & 0 & 0 & 0 & 0 & 0 & 0 & 0 & 0 & 1 & 1 & 0 & 0 & 0 \\
\hline & Lepomis macrochirus & 0 & 0 & 0 & 0 & 0 & 0 & 0 & 0 & 0 & 0 & 0 & 0 & 0 \\
\hline & Micropterus dolomieu & 1 & 1 & 0 & 0 & 0 & 1 & 0 & 1 & 1 & 1 & 1 & 1 & 1 \\
\hline & Micropterus salmoides & 1 & 0 & 0 & 0 & 0 & 1 & 0 & 1 & 1 & 1 & 1 & 0 & 1 \\
\hline & Pomoxis annularis & 0 & 0 & 0 & 0 & 0 & 0 & 0 & 0 & 0 & 0 & 0 & 0 & 0 \\
\hline & Pomoxis nigromaculatus & 1 & 1 & 0 & 0 & 0 & 0 & 0 & 0 & 1 & 1 & 0 & 0 & 0 \\
\hline Clupeidae & Alosa pseudoharengus & 0 & 1 & 1 & 0 & 1 & 0 & 0 & 0 & 1 & 1 & 0 & 0 & 1 \\
\hline Clupeidae & Dorosoma cepedianum & 1 & 0 & 0 & 0 & 0 & 0 & 1 & 0 & 0 & 0 & 0 & 0 & 0 \\
\hline \multirow[t]{12}{*}{ Cyprinidae } & Carassius auratus & 1 & 0 & 0 & 0 & 0 & 0 & 0 & 0 & 0 & 0 & 0 & 0 & 0 \\
\hline & Cyprinella spiloptera & 0 & 0 & 0 & 0 & 0 & 0 & 0 & 0 & 0 & 0 & 0 & 0 & 0 \\
\hline & Cyprinus carpio & 1 & 1 & 1 & 0 & 0 & 0 & 0 & 0 & 1 & 1 & 1 & 0 & 1 \\
\hline & Hybognathus hankinsoni & 0 & 0 & 0 & 0 & 0 & 0 & 0 & 0 & 0 & 0 & 0 & 0 & 0 \\
\hline & Notemigonus crysoleucas & 0 & 0 & 0 & 0 & 0 & 0 & 0 & 0 & 0 & 1 & 0 & 0 & 0 \\
\hline & Notropis atherinoides & 0 & 0 & 1 & 0 & 0 & 0 & 0 & 0 & 0 & 1 & 0 & 0 & 1 \\
\hline & Notropis heterolepis & 0 & 0 & 0 & 0 & 0 & 0 & 0 & 0 & 0 & 0 & 0 & 0 & 0 \\
\hline & Notropis hudsonius & 0 & 0 & 0 & 0 & 0 & 0 & 0 & 0 & 1 & 0 & 0 & 1 & 0 \\
\hline & Notropis stramineus & 0 & 0 & 0 & 0 & 0 & 0 & 0 & 0 & 0 & 0 & 0 & 0 & 0 \\
\hline & Pimephales notatus & 0 & 1 & 0 & 0 & 0 & 0 & 0 & 0 & 1 & 0 & 0 & 0 & 0 \\
\hline & Pimephales promelas & 0 & 0 & 0 & 0 & 0 & 0 & 0 & 0 & 1 & 0 & 0 & 0 & 0 \\
\hline & Scardinius erythrophthalmus & 0 & 0 & 0 & 0 & 0 & 0 & 0 & 0 & 0 & 0 & 0 & 0 & 0 \\
\hline Esocidae & Esox americanus & 0 & 0 & 0 & 0 & 0 & 0 & 0 & 0 & 0 & 0 & 0 & 0 & 0 \\
\hline Esocidae & Esox lucius & 1 & 1 & 1 & 0 & 0 & 1 & 0 & 1 & 1 & 1 & 1 & 1 & 1 \\
\hline Fundulidae & Fundulus diaphanus & 0 & 0 & 0 & 0 & 0 & 0 & 0 & 0 & 1 & 0 & 0 & 0 & 0 \\
\hline Gasterosteidae & Gasterosteus aculeatus & 0 & 0 & 1 & 0 & 1 & 0 & 0 & 0 & 0 & 0 & 0 & 1 & 1 \\
\hline Gobiidae & Neogobius melanostomus & 0 & 0 & 0 & 0 & 0 & 0 & 0 & 0 & 0 & 0 & 0 & 0 & 0 \\
\hline \multirow[t]{4}{*}{ Ictaluridae } & Ameiurus melas & 0 & 0 & 0 & 0 & 0 & 0 & 0 & 0 & 0 & 0 & 0 & 0 & 0 \\
\hline & Ameiurus nebulosus & 1 & 0 & 1 & 0 & 0 & 0 & 0 & 0 & 1 & 1 & 1 & 1 & 1 \\
\hline & Ictalurus punctatus & 0 & 0 & 0 & 0 & 0 & 0 & 0 & 0 & 0 & 1 & 0 & 0 & 0 \\
\hline & Noturus gyrinus & 0 & 0 & 0 & 0 & 0 & 0 & 0 & 0 & 0 & 0 & 0 & 0 & 0 \\
\hline Lepisosteidae & Lepisosteus osseus & 0 & 0 & 0 & 0 & 0 & 0 & 0 & 0 & 0 & 0 & 0 & 0 & 0 \\
\hline \multirow[t]{2}{*}{ Moronidae } & Morone americana & 1 & 0 & 1 & 0 & 0 & 0 & 1 & 0 & 1 & 1 & 1 & 0 & 1 \\
\hline & Morone chrysops & 0 & 0 & 0 & 1 & 0 & 0 & 0 & 0 & 0 & 0 & 0 & 0 & 0 \\
\hline Percidae & Etheostoma nigrum & 0 & 0 & 0 & 0 & 0 & 0 & 0 & 0 & 1 & 0 & 0 & 0 & 1 \\
\hline Percidae & Perca flavescens & 0 & 0 & 1 & 1 & 0 & 1 & 1 & 0 & 1 & 1 & 1 & 0 & 1 \\
\hline Salmonidae & Oncorhynchus tshawytscha & 0 & 0 & 0 & 0 & 0 & 0 & 0 & 0 & 0 & 0 & 0 & 0 & 0 \\
\hline Sciaenidae & Aplodinotus grunniens & 0 & 0 & 0 & 0 & 0 & 0 & 0 & 0 & 0 & 0 & 0 & 0 & 1 \\
\hline Umbridae & Umbra limi & 0 & 0 & 0 & 0 & 0 & 0 & 0 & 0 & 0 & 0 & 0 & 0 & 0 \\
\hline
\end{tabular}


Table 7: Recent fish occurrence. See Table 2 for site codes.

\begin{tabular}{|c|c|c|c|c|c|c|c|c|c|c|c|c|c|c|}
\hline \multirow[b]{2}{*}{ Family } & \multirow[b]{2}{*}{ Scientific name } & \multicolumn{13}{|c|}{ Recent fish collection } \\
\hline & & A & B & $\mathrm{C}$ & $\mathrm{D}$ & $\mathrm{E}$ & $\mathrm{F}$ & G & $\mathrm{H}$ & I & $\mathrm{J}$ & K & $\mathrm{L}$ & M \\
\hline Amiidae & Amia calva & 1 & 0 & 1 & 0 & 1 & 0 & 1 & 1 & 1 & 1 & 1 & 1 & 1 \\
\hline Anguillidae & Anguilla rostrata & 0 & 0 & 0 & 0 & 0 & 0 & 0 & 0 & 1 & 0 & 0 & 0 & 0 \\
\hline Atherinopsidae & Labidesthes sicculus & 0 & 0 & 0 & 0 & 0 & 0 & 0 & 0 & 0 & 1 & 0 & 0 & 0 \\
\hline Catostomidae & Catostomus commersonii & 0 & 1 & 0 & 0 & 0 & 0 & 0 & 0 & 0 & 0 & 0 & 0 & 0 \\
\hline \multirow[t]{8}{*}{ Centrarchidae } & Ambloplites rupestris & 1 & 1 & 1 & 0 & 1 & 1 & 1 & 1 & 1 & 1 & 0 & 1 & 0 \\
\hline & Lepomis cyanellus & 1 & 0 & 0 & 0 & 0 & 0 & 0 & 0 & 0 & 0 & 0 & 0 & 0 \\
\hline & Lepomis gibbosus & 1 & 1 & 1 & 1 & 1 & 1 & 1 & 1 & 1 & 1 & 1 & 1 & 1 \\
\hline & Lepomis macrochirus & 1 & 1 & 0 & 0 & 1 & 1 & 1 & 0 & 0 & 1 & 1 & 0 & 1 \\
\hline & Micropterus dolomieu & 1 & 0 & 0 & 0 & 0 & 0 & 0 & 0 & 0 & 0 & 0 & 0 & 0 \\
\hline & Micropterus salmoides & 1 & 0 & 1 & 1 & 1 & 1 & 1 & 1 & 0 & 0 & 1 & 0 & 1 \\
\hline & Pomoxis annularis & 1 & 0 & 1 & 1 & 0 & 0 & 0 & 0 & 0 & 0 & 0 & 0 & 0 \\
\hline & Pomoxis nigromaculatus & 0 & 0 & 0 & 0 & 0 & 0 & 0 & 0 & 1 & 0 & 0 & 0 & 1 \\
\hline Clupeidae & Alosa pseudoharengus & 1 & 1 & 1 & 0 & 0 & 0 & 0 & 0 & 0 & 1 & 0 & 0 & 0 \\
\hline Clupeidae & Dorosoma cepedianum & 1 & 0 & 1 & 1 & 0 & 0 & 0 & 0 & 0 & 0 & 0 & 0 & 0 \\
\hline \multirow[t]{12}{*}{ Cyprinidae } & Carassius auratus & 0 & 1 & 0 & 0 & 0 & 0 & 0 & 0 & 0 & 0 & 0 & 0 & 0 \\
\hline & Cyprinella spiloptera & 0 & 1 & 0 & 0 & 0 & 0 & 0 & 0 & 0 & 1 & 0 & 0 & 0 \\
\hline & Cyprinus carpio & 1 & 0 & 1 & 1 & 1 & 0 & 0 & 1 & 0 & 0 & 0 & 0 & 1 \\
\hline & Hybognathus hankinsoni & 0 & 1 & 0 & 0 & 0 & 0 & 0 & 0 & 0 & 0 & 0 & 0 & 0 \\
\hline & Notemigonus crysoleucas & 1 & 1 & 0 & 0 & 0 & 1 & 0 & 0 & 1 & 1 & 0 & 0 & 0 \\
\hline & Notropis atherinoides & 0 & 1 & 0 & 0 & 0 & 0 & 0 & 0 & 1 & 0 & 0 & 0 & 0 \\
\hline & Notropis heterolepis & 0 & 0 & 0 & 0 & 0 & 0 & 0 & 0 & 0 & 1 & 0 & 1 & 0 \\
\hline & Notropis hudsonius & 1 & 1 & 1 & 0 & 0 & 0 & 0 & 0 & 1 & 0 & 0 & 0 & 0 \\
\hline & Notropis stramineus & 0 & 1 & 0 & 0 & 0 & 0 & 0 & 0 & 0 & 0 & 0 & 0 & 0 \\
\hline & Pimephales notatus & 1 & 1 & 1 & 0 & 0 & 1 & 1 & 0 & 1 & 1 & 0 & 1 & 0 \\
\hline & Pimephales promelas & 1 & 1 & 1 & 0 & 0 & 0 & 0 & 0 & 1 & 1 & 0 & 0 & 0 \\
\hline & Scardinius erythrophthalmus & 0 & 0 & 0 & 0 & 0 & 0 & 0 & 0 & 0 & 0 & 0 & 0 & 0 \\
\hline Esocidae & Esox americanus & 0 & 0 & 0 & 0 & 0 & 0 & 0 & 0 & 0 & 0 & 1 & 0 & 0 \\
\hline Esocidae & Esox lucius & 0 & 0 & 0 & 1 & 0 & 1 & 1 & 0 & 0 & 1 & 0 & 1 & 0 \\
\hline Fundulidae & Fundulus diaphanus & 0 & 0 & 0 & 0 & 1 & 1 & 1 & 1 & 1 & 1 & 0 & 0 & 1 \\
\hline Gasterosteidae & Gasterosteus aculeatus & 0 & 1 & 0 & 0 & 0 & 0 & 0 & 0 & 0 & 1 & 0 & 0 & 0 \\
\hline Gobiidae & Neogobius melanostomus & 0 & 0 & 0 & 0 & 0 & 0 & 0 & 0 & 0 & 0 & 0 & 0 & 0 \\
\hline \multirow[t]{4}{*}{ Ictaluridae } & Ameiurus melas & 0 & 0 & 0 & 0 & 1 & 0 & 0 & 0 & 0 & 0 & 0 & 0 & 0 \\
\hline & Ameiurus nebulosus & 1 & 1 & 1 & 1 & 1 & 1 & 1 & 1 & 1 & 1 & 1 & 1 & 1 \\
\hline & Ictalurus punctatus & 1 & 0 & 0 & 0 & 0 & 0 & 0 & 0 & 0 & 0 & 0 & 0 & 0 \\
\hline & Noturus gyrinus & 0 & 0 & 1 & 0 & 1 & 1 & 0 & 1 & 0 & 1 & 0 & 1 & 0 \\
\hline Lepisosteidae & Lepisosteus osseus & 0 & 0 & 0 & 0 & 0 & 0 & 0 & 0 & 0 & 1 & 0 & 0 & 0 \\
\hline \multirow[t]{2}{*}{ Moronidae } & Morone americana & 1 & 0 & 0 & 0 & 0 & 0 & 0 & 0 & 0 & 0 & 0 & 0 & 0 \\
\hline & Morone chrysops & 0 & 0 & 1 & 0 & 0 & 0 & 0 & 0 & 0 & 0 & 0 & 0 & 0 \\
\hline Percidae & Etheostoma nigrum & 0 & 0 & 1 & 0 & 0 & 0 & 0 & 0 & 0 & 1 & 0 & 0 & 1 \\
\hline Percidae & Perca flavescens & 1 & 0 & 1 & 1 & 1 & 1 & 1 & 1 & 1 & 1 & 1 & 1 & 1 \\
\hline Salmonidae & Oncorhynchus tshawytscha & 0 & 0 & 0 & 0 & 0 & 0 & 0 & 0 & 0 & 0 & 0 & 0 & 0 \\
\hline Sciaenidae & Aplodinotus grunniens & 0 & 0 & 0 & 0 & 0 & 0 & 0 & 0 & 0 & 0 & 0 & 0 & 0 \\
\hline Umbridae & Umbra limi & 0 & 0 & 0 & 0 & 1 & 0 & 1 & 0 & 0 & 1 & 0 & 1 & 1 \\
\hline
\end{tabular}


Although lake-wide total phosphorus loadings have declined since the 1980s and the overall water quality in Lake Ontario has improved [15], the magnitude of improvements and benefits varies regionally. Such geographic differences are reflected in variation of WFI scores throughout the basin; for instance, in the Bay of Quinte, where phosphorus concentrations has been drastically reduced through the Bay of Quinte RAP [25], we have seen an increase in the number of Centrarchidae and Cyprinidae species that corresponds to the largest increase in WFI scores between time periods for two associated wetlands (Presqu'ile Provincial Park and Hay Bay Marsh). Abundance of yellow perch Perca flavescens [26] and largemouth bass [27] have increased in Bay of Quinte with the reduction of phosphorus. Trophic status has also changed in the nearshore areas of northeastern Lake Ontario, adjacent to Perch River/Muskellunge River site, from mesotrophic (moderate TP in 1978) to oligotrophic (low TP in 1995; [28]). Accompanying the trophic shift, O'Gorman and Burnett [28] reported changes in the warm-water fish community and reduced fish density, while we found an above average increase in WFI score (Perch River/Muskellunge River +0.63 versus overall average +0.33 ).

Effective management of the fish communities in Lake Ontario wetlands needs to be done on a basin-wide scale. The Lake Ontario Lake-wide Management Plan (LAMP), as part of the GLWQA of 1987, identifies near-shore wetlands as a main habitat in Lake Ontario, along with three other zones: offshore ( $>15 \mathrm{~m})$, nearshore, and tributaries [29]. Two lakewide problems identified in the LAMP were restrictions on fish consumption and loss of fish habitat [29]. The whole-lake context allows for stronger conclusions to be drawn in regard to the effectiveness of remediation. Kelso and Minns [30] found that on a basin-wide scale the fish assemblages varied more by region than between AOC and non-AOC sites. We have eliminated the confounding effects of geographical difference in ecoregions by focusing on a single Great Lake, which allows us to compare the differences between AOC and non-AOC sites. It is important that benefits accrued at the scale of Lake Ontario be explicitly recognized in studies such as ours, even if specific remedial actions associated with a particular AOC (e.g., improved fish habitat or water quality) cannot be demonstrated (e.g., the lack of change in WFI scores associated with Cootes Paradise Marsh).

We acknowledge that there are differences in surveying methods used to collect data between time periods, but the type of sampling gear is not expected to dramatically affect presence/absence data. Even though we did not have ideal datasets, we believe that it is an appropriate and necessary comparison. Kelso and Minns [30] used Fish Species Distribution Data System data for comparisons with AOC sites, which were collected from 1920s to 1990 at different times of year and with different fish gear types. Fish data from the atlas was collected and compiled for nursery and spawning habitat with the express purpose of providing a database "against which changes in the condition and use of spawning and nursery habitat of Great Lakes fishes could be viewed and evaluated" [17].

\section{Conclusion}

This study with 13 representative coastal wetlands distributed throughout the Lake Ontario shoreline has shown that both the total number of species and families of fish have changed significantly since the early 1980s. These differences were reflected in corresponding WFI scores that were calculated by using only presence-absence data. We quantified the degree of improvement in wetland condition at each site and were able to explicitly link these improvements to lake-wide implementation of Remedial Action Plans. Although RAPs have led to recovery of ecological functions on a lake-wide basis, health of urbanized wetlands, especially those at the western end of the lake, will be severely compromised by non-point-source pollution resulting from increased human populations over the next decade. Future work should focus on developing monitoring programs that take into account both local and lake-wide assessments of both the fish community and water-quality conditions.

\section{Acknowledgments}

This research would not have been possible without the capable expertise of K. Kostuk and S. McNair. N. Collins, D. Gerten, C. Rixen, and an anonymous reviewer provided helpful comments that greatly improved the statistical analysis and results section. Funding for this study was provided by the Great Lakes Fishery Commission. The present addresses of T. Seilheimer and A. Wei are Northern Research Station, USDA Forest Service, 1992 Folwell Avenue, Saint Paul, MN 55108, USA and Department of Environment and Natural Resources, Government of the Northwest Territories, Box 2749, Inuvik, NT, Canada X0E 0T0, respectively.

\section{References}

[1] International Joint Commission (IJC), The Great Lakes Areas of Concern Report, Ottawa, Canada, 2003.

[2] D. J. Jude and J. Pappas, "Fish utilization of Great Lakes coastal wetlands," Journal of Great Lakes Research, vol. 18, no. 4, pp. 651-672, 1992.

[3] A. Wei, P. Chow-Fraser, and D. Albert, "Influence of shoreline features on fish distribution in the Laurentian Great Lakes," Canadian Journal of Fisheries and Aquatic Sciences, vol. 61, no. 7, pp. 1113-1123, 2004.

[4] T. H. Whillans, "Changes in marsh area along the Canadian shore of Lake Ontario ( Bay of Quinte)," Journal of Great Lakes Research, vol. 8, no. 3, pp. 570-577, 1982.

[5] P. Chow-Fraser, "Development of the Wetland Water Quality Index (WQI) to assess effects of basin-wide land-use alteration on coastal marshes of the Laurentian Great Lakes," in Coastal Wetlands of the Laurentian Great Lakes: Health, Habitat and Indicators, T. P. Simon and P. M. Stewart, Eds., chapter 5, pp. 233-256, Bloomington, Ind, USA, Indiana Biological Survey, 2006.

[6] D. A. Albert and L. D. Minc, "Plants as regional indicators of Great Lakes coastal wetland health," Aquatic Ecosystem Health and Management, vol. 7, no. 2, pp. 233-247, 2004. 
[7] V. L. Lougheed and P. Chow-Fraser, "Development and use of a zooplankton index of wetland quality in the Laurentian Great Lakes Basin," Ecological Applications, vol. 12, no. 2, pp. 474-486, 2002.

[8] T. M. Burton, D. G. Uzarski, J. P. Gathman, J. A. Gene, B. E. Keas, and C. A. Stricker, "Development of a preliminary invertebrate index of biotic integrity for Lake Huron coastal wetlands," Wetlands, vol. 19, no. 4, pp. 869-882, 1999.

[9] J. R. Karr, "Assessment of biotic integrity using fish communities," Fisheries, vol. 6, no. 6, pp. 21-27, 1981.

[10] J. Lyons, R. R. Piette, and K. W. Niermeyer, "Development, validation, and application of a fish-based index of biotic integrity for Wisconsin's large warmwater rivers," Transactions of the American Fisheries Society, vol. 130, no. 6, pp. 10771094, 2001.

[11] J. R. Karr, "Biological integrity: a long-neglected aspect of water resource management," Ecological Applications, vol. 1, no. 1, pp. 66-84, 1991.

[12] C. K. Minns, V. W. Cairns, R. G. Randall, and J. E. Moore, "An index of biotic integrity (IBI) for fish assemblages in the littoral zone of Great lakes' areas of concern," Canadian Journal of Fisheries and Aquatic Sciences, vol. 51, no. 8, pp. 1804-1822, 1994.

[13] R. J. Steedman, "Modification and assessment of an index of biotic integrity to quantify stream quality in southern Ontario," Canadian Journal of Fisheries and Aquatic Sciences, vol. 45, no. 3, pp. 492-501, 1988.

[14] T. S. Seilheimer and P. Chow-Fraser, "Development and use of the Wetland Fish Index to assess the quality of coastal wetlands in the Laurentian Great Lakes," Canadian Journal of Fisheries and Aquatic Sciences, vol. 63, no. 2, pp. 354-366, 2006.

[15] E. L. Mills, J. M. Casselman, R. Dermott et al., "Lake Ontario: food web dynamics in a changing ecosystem (1970-2000)," Canadian Journal of Fisheries and Aquatic Sciences, vol. 60, no. 4, pp. 471-490, 2003.

[16] T. J. Stewart, R. E. Lange, S. D. Orsatti, C. P. Schneider, A. Mathers, and M. E. Daniels, Fish Community Objectives for Lake Ontario, Great Lakes Fishery Commission, 1999.

[17] C. S. Goodyear, T. A. Edsall, D. M. Ormsby Dempsey, G. D. Moss, and P. E. Polanski, "Atlas of the spawning and nursery areas of Great Lakes fishes," FWS/OBS-82/52, US Fish and Wildlife Service, Washington, DC, USA, 1982.

[18] J. H. Zar, Biostatistical Analysis, Prentice Hall, Upper Saddle River, NJ, USA, 4th edition, 1999.

[19] T. A. Waite and L. G. Campbell, "Controlling the false discovery rate and increasing statistical power in ecological studies," Ecoscience, vol. 13, no. 4, pp. 439-442, 2006.

[20] C. S. Findlay and J. Houlahan, "Anthropogenic correlates of species richness in southeastern Ontario wetlands," Conservation Biology, vol. 11, no. 4, pp. 1000-1009, 1997.

[21] M. J. Paul and J. L. Meyer, "Streams in the urban landscape," Annual Review of Ecology and Systematics, vol. 32, pp. 333-365, 2001.

[22] L. Wang, J. Lyons, and P. Kanehl, "Impacts of urban land cover on trout streams in Wisconsin and Minnesota," Transactions of the American Fisheries Society, vol. 132, no. 5, pp. 825-839, 2003.

[23] A. Wei and P. Chow-Fraser, "Synergistic impact of water level fluctuation and invasion of Glyceria on Typha in a freshwater marsh of Lake Ontario," Aquatic Botany, vol. 84, no. 1, pp. 6369, 2006.
[24] Statistics Canada, “Annual Demographic Statistics," Tech. Rep. 91-213-XIB, Statistics Canada, Ottawa, Canada, 2005.

[25] K. H. Nicholls, L. Heintsch, and E. Carney, "Univariate steptrend and multivariate assessments of the apparent effects of $\mathrm{P}$ loading reductions and zebra mussels on the phytoplankton of the Bay of Quinte, Lake Ontario," Journal of Great Lakes Research, vol. 28, no. 1, pp. 15-31, 2002.

[26] J. A. Hoyle and T. Schaner, "Lake Ontario nearshore fish community," in Lake Ontario Fish Communities and Fisheries. Annual Report of the Lake Ontario Management Unit, chapter 3, pp. 1-7, Queen's Printer for Ontario, Ontario, Canada, 2001.

[27] J. A. Hoyle, "Bay of Quinte recreational fishery," in Lake Ontario Fish Communities and Fisheries. Annual Report of the Lake Ontario Management Unit, chapter 7, pp. 1-3, Queen's Printer for Ontario, Ontario, Canada, 2001.

[28] R. O'Gorman and J. A. D. Burnett, "Fish community dynamics in Northeastern Lake Ontario with emphasis on the growth and reproductive success of yellow perch (Perca flavescens) and white perch (Morone americana), 1978 to 1997," Journal of Great Lakes Research, vol. 27, no. 3, pp. 367-383, 2001.

[29] Lake Ontario LaMP, The Lake Ontario lakewide management plan. Environment Canada, Ontario Region and U.S. Environmental Protection Agency, Region 2, 1998, http://www.epa .gov/glnpo/lakeont/lola/index.html.

[30] J. R. M. Kelso and C. K. Minns, "Is fish species richness at sites in the Canadian Great Lakes the result of local or regional factors?" Canadian Journal of Fisheries and Aquatic Sciences, vol. 53, no. 1, pp. 175-190, 1996. 

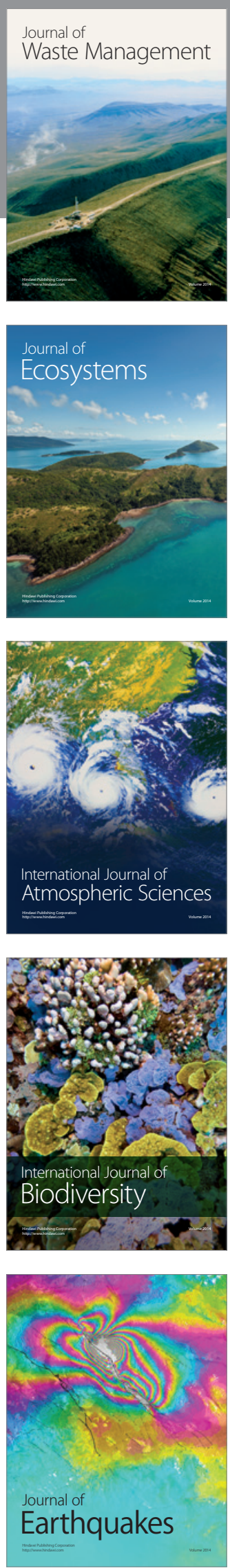
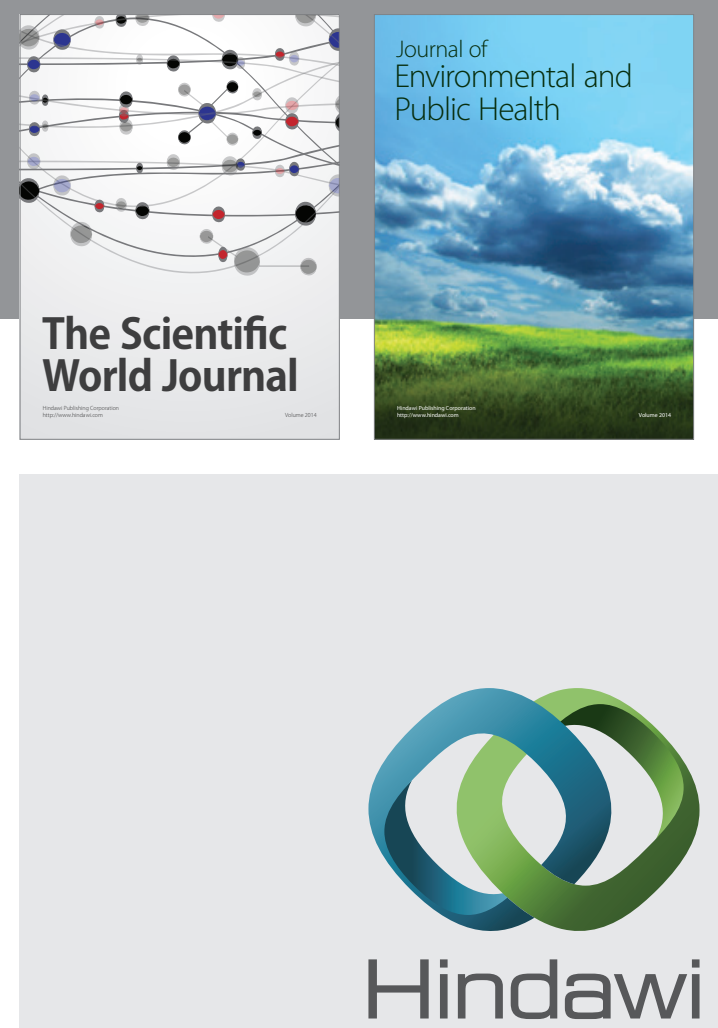

Submit your manuscripts at

http://www.hindawi.com
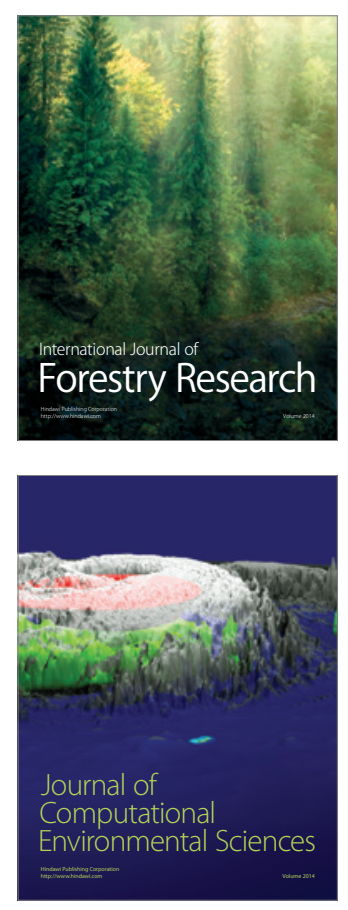
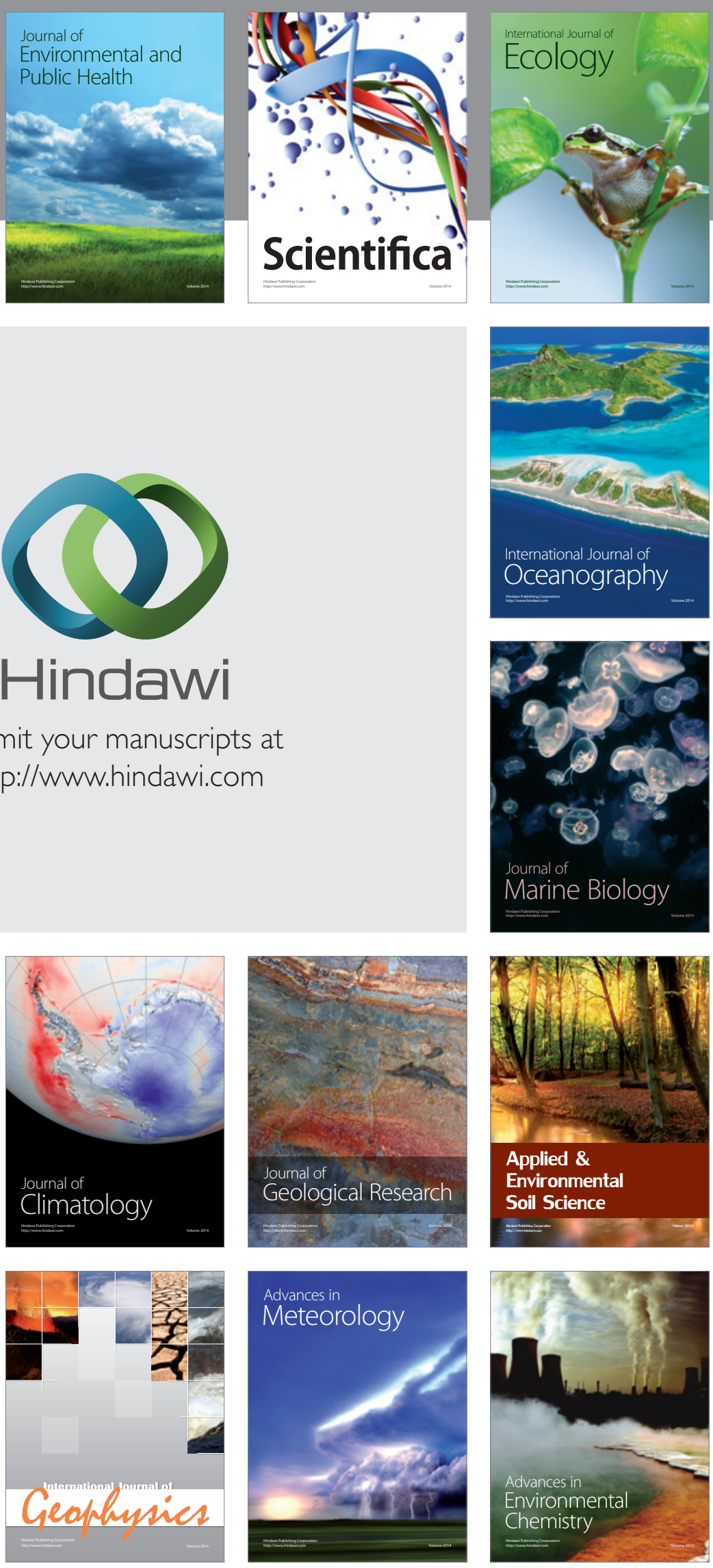